\title{
Open Innovation of New Emerging Small Economies Based on University-Construction Industry Cooperation
}

\author{
Zane Rostoka, Jevgenijs Locovs and Elīna Gaile-Sarkane * \\ Faculty of Engineering Economics and Management, Riga LV-1048, Latvia; zane.rostoka@rtu.lv (Z.R.); \\ jevgenijs.locovs@gmail.com (J.L.) \\ * Correspondence: elina.gaile-sarkane@rtu.lv; Tel.: +371-67089394
}

Received: 12 October 2018; Accepted: 21 January 2019; Published: 16 February 2019

\begin{abstract}
This research is to analyse the existing cooperation between universities and the construction industry and to investigate what is the most effective model for long-term cooperation between an academic university and the private construction sector. The current article describes the human resources management tools to be used by employers to create interrelations between the paid salaries and productivity, thus providing both individual and corporate results. The suggested different tools contribute to keeping employees satisfied and motivated, simultaneously properly balancing productivity and individual earnings. The researchers conclude that it is necessary to create a new model for personnel selection and a new approach to stimulate motivation and maintenance within the construction industry. In order to respond to the needs of the sector for professionals and the required increase of the qualifications of the mentioned specialists, it is necessary that the country improves the level of education of the future professionals for the construction industry and changes the system of testing their professional qualifications, which means cooperation between the educational institutions and the industry. The suggested cooperation model by authors may provide a general guideline for further detailed researches and its implementation may help similar-sized economies to make possible national adjustments. The implementation of this model in bigger and/or developed economies should be justified by separate additional research.
\end{abstract}

Keywords: human capital; construction industry; cooperation model; sustainability; expert opinion survey

\section{Introduction}

The situation in the Latvian labour market continues to improve as employment is increasing and unemployment is decreasing, however, since 2015, employers have been discussing the shortage of qualified labour force, the increasing demands of potential employees, the turnover of existing staff and free access to other EU markets with better job offers.

Assessing the situation in the construction industry, the observation shows a high human resource turnover and a lack of qualified and motivated staff. The researchers conclude that it is necessary to create a new model for personnel selection and a new approach to stimulate motivation and maintenance within the construction industry. In order to respond to the needs of the sector for professionals and the required increase of the qualifications of the mentioned specialists, it is necessary that the country improves the level of education of the future professionals for the construction industry and changes the system of testing their professional qualifications, which means cooperation between the educational institutions and the industry.

The business ecosystem (researched by Isenberg [1]) plays an important role in the cooperation between the educational institutions and the industry on various levels, and it mostly encompasses a 
social and economic environment (based on Triple Helix conception [2]) that affects the local businesses. According to Mangiaralardo and Micelli [3], the construction industry has to undergo a radical change, taking into account new social, cultural and economic aspects.

To facilitate the competition, a system must be created where each person that is employed in the construction field must prove his/her level of professional qualities. As a result, there are changes in the business environment and technologies and there appears to be an understanding within the human resources of companies on how to properly manage the staff to reach the required results by constantly adjusting and developing the approach. The professional requirements also undergo changes where new levels of competence and professional approaches are expected; here, the cooperation between the educational institutions and the industry plays a significant role.

Furthermore, this article is describing the human resources management tools to be used by employers to create interrelations between the paid salaries and productivity, thus providing both individual and corporate results. The suggested different tools contribute to keeping employees satisfied and motivated, simultaneously properly balancing productivity and individual earnings.

The aim of this research is to analyse the existing cooperation between universities and the construction industry and to investigate what is the most effective model for long-term cooperation between an academic university and the private construction sector. This research makes an assessment of university-industry cooperation by focusing on what the participants, faculty members and companies and their employees actually get out of their cooperation and to determine how participants in university-industry cooperate: faculty members and companies rate the relative importance of cooperation reasons and make a new cooperation model for achieving the strategic goals of stakeholders.

\section{Research Methodology}

The methodology used for this research is an interpretative research paradigm where an activity of an individual as a social phenomenon is considered; here, an individual is expressing oneself in a certain social environment and context [4]. The study is based on parallel use of quantitative and qualitative methods. Qualitative and quantitative data are concurrently gathered, then summarised and analysed mostly based on case studies in order to integrate the study results into a comprehensive human resource development model. The researchers aim to reach a conclusion based on the cooperation between the educational institutions and the construction industry. In the course of the study, the triangulation method is applied by carrying out the empirical study and using the study results obtained through expert interviews and from focus groups.

\subsection{Analysis of the Construction Industry of Emerging Small Economies}

\subsubsection{Analysis of Construction Industry Cases in Latvia}

The authors have reviewed and analysed the main figures within the industry-turnover in total, the number of construction companies and the industry division in terms of scale. According to the Law on the Annual Financial Statements and Consolidated Financial Statements, there are four groups of undertakings-large companies are considered the ones that annually exceed two of the following three indicators: the total balance sheet of EUR 20 million, the net turnover of EUR 40 million and the total number of employees-250; medium-sized enterprises are companies that do not exceed two of the above-mentioned three indicators and exceed two of the following three indicators: the total balance sheet of EUR 4 million, the net turnover of EUR 8 million and 50 employees; the companies that do not exceed two of the above mentioned indicators are considered small. Micro undertakings are all those that do not fulfil the requirements that are needed to access the group of small entities (based on [5]).

The research period is from January 2016 until June 2018, with the analysis of statistical data for the period from 2006 to 2017. 
The desk research started on April 2016 with analysis of the current situation and the detection of the main factors that affect University-Construction Industry Cooperation. Initially, three (Finland, Ireland and Netherlands) developed economies and one emerging (Latvia) economy that either have similar demographic or geographical scale were compared. According to Bosma and Amorós [6], The Netherlands, Ireland and Finland are innovation driven economies, while Latvia is among countries that are efficiency driven. Erkut [7] found that economists from efficiency-driven countries see bigger opportunities for potential entrepreneurs in these economies than in other stages of economic growth. It may be more common for innovation-driven economies to have entrepreneurs who are scientists or engineers, or entrepreneurs who can commercialize the ideas of scientists and engineers with their firms.

The statistical data of the demographics, economics, labour costs, education, level of trust in state institutions and distribution of the EU funds was analysed (Tables 1-3).

Table 1. Population of Latvia, Ireland, Finland and Netherlands in comparison (based on Worldbank [8], Eurostat [9]).

\begin{tabular}{|c|c|c|c|c|c|c|c|c|}
\hline & \multicolumn{2}{|c|}{ Latvia } & \multicolumn{2}{|c|}{ Ireland } & \multicolumn{2}{|c|}{ Finland } & \multicolumn{2}{|c|}{ Netherlands } \\
\hline Area $\mathrm{km}^{2}$ & \multicolumn{2}{|c|}{64,589} & \multicolumn{2}{|c|}{68,890} & \multicolumn{2}{|c|}{303,890} & \multicolumn{2}{|c|}{33,690} \\
\hline Year & 2006 & 2015 & 2006 & 2015 & 2006 & 2015 & 2006 & 2015 \\
\hline $\begin{array}{c}\text { Population density } \\
\text { (people per square km } \\
\text { of land area) }\end{array}$ & 36 & 32 & 62 & 67 & 17 & 18 & 484 & 503 \\
\hline Year & 2006 & 2015 & 2006 & 2015 & 2006 & 2015 & 2006 & 2015 \\
\hline Population total & $2,227,874$ & $1,968,957$ & $4,208,156$ & $4,724,720$ & $5,255,580$ & $5,487,308$ & $16,334,210$ & $16,979,120$ \\
\hline
\end{tabular}

Table 2. Labour costs 2015 year (based on Eurostat [10], Deloitte [11], Central Statistical Bureau of Latvia [12]).

\begin{tabular}{ccccc}
\hline Country & $\begin{array}{c}\text { Net Annual Income } \\
\text { (Average Single, No } \\
\text { Kids) Eur }\end{array}$ & $\begin{array}{c}\text { Annual Labour Costs } \\
\text { (Average Single, No } \\
\text { Kids) Eur }\end{array}$ & $\begin{array}{c}\text { Net/Labour Costs } \\
\text { Ratio \% }\end{array}$ & $\begin{array}{c}\text { Labour Productivity } \\
\text { Index }\end{array}$ \\
\hline Latvia & 10,500 & 18,420 & 57 & 5.4 \\
\hline Ireland & 30,000 & 54,545 & 55 & 38.8 \\
\hline Finland & 28,000 & 46,200 & 60 & 58.7 \\
\hline Netherlands & 34,500 & 69,000 & 50 & 58.2 \\
\hline
\end{tabular}

Table 3. Apparent labour productivity in construction 2013 year.

\begin{tabular}{ccc}
\hline Country & $\begin{array}{c}\text { Apparent Labour Productivity in } \\
\text { Construction Eur Thousand per Head }\end{array}$ & $\begin{array}{c}\text { The Difference in Productivity } \\
\text { (Latvia = 1) Times }\end{array}$ \\
\hline Latvia & 12.8 & 1 \\
\hline Ireland & $\mathrm{n} / \mathrm{a}$ & $\mathrm{n} / \mathrm{a}$ \\
\hline Finland & 44.8 & 3.5 \\
\hline Netherlands & 51.0 & 4 \\
\hline
\end{tabular}

Comparing different indexes of costs of living, rent, groceries, restaurant price and local purchasing power, it appeared that residents of Latvia enjoy about a $40 \%-50 \%$ lower cost of living and pricing, whilst on the other hand, residents of Ireland, Finland or Netherlands pose double purchasing power [13]. This data supports authors' assumption that emerging economies should improve via stimulation of productivity. That, in turn, should source its growth in well-educated and professional human capital.

The Netherlands has 12 universities that were included in the Times Higher Education World University Rankings 2016-2017 [14] (seven are in the top 100). Ireland and Finland each have nine 
universities ranked (one in the top 100 per country), while Latvia has only two universities ranked at all and these educational entities are placed at the 801st + . Data related to the ranking of the universities in the four observed countries is displayed in Figure 1. The low level of the education creates a vicious circle where unskilled and unmotivated young professionals are not able to contribute to the development of the economy in general, not to mention a particular industry (Based on World University Rankings 2016-2017).

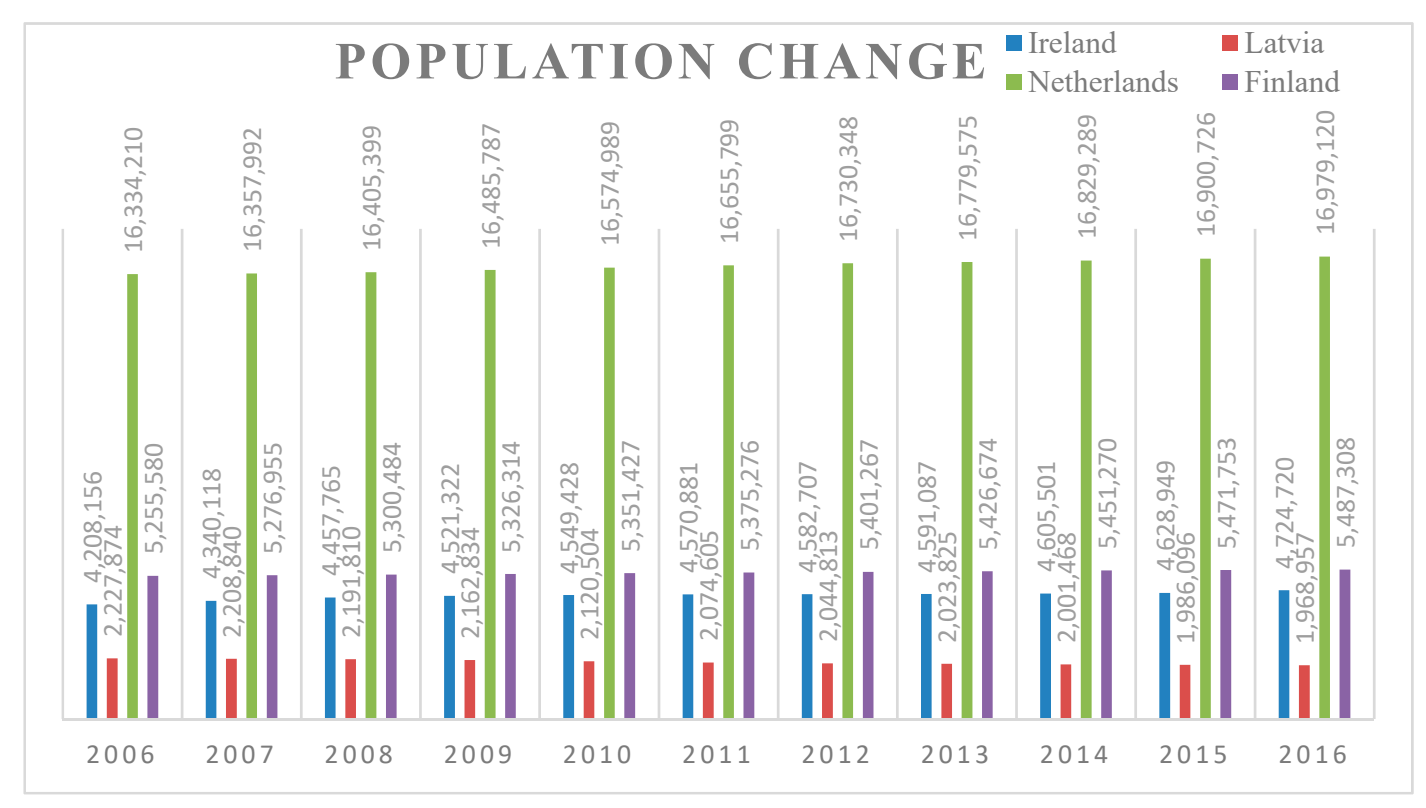

Figure 1. Population change data 2006-2016 (based on Eurostat, 2017 [9]).

The level of trust in National institutions in Latvia is less than that of the EU average, however it shows a moderate improvement. Despite the positive change in the perception and trust in institutions, both of these factors are far behind those of the developed economies.

The other significant point that affects Latvian economy is the receipt and distribution of the EU Funds. In 2007-2013, Latvia received 4.6 billion Euros and the budget plan was made to provide 5.63 billion Euros in 2014-2020 from European structural and Investments funds. For instance, COHESION POLICY FUNDING as a percentage of governmental capital investment in 2007-2013 was as following: Ireland $-0.7 \%$, the Netherlands $-0.4 \%$, Finland $-1.7 \%$ and Latvia $-50.5 \%$. According to the indicative plan of the Central Finance and Contracting Agency (CFCA), the major part of the tendering process started in 2016 or is planned to be started in 2017, which means that it will cause a rush in the realization of these projects, requiring them to be completed within three years instead of six years (Based on Infographics about EU Funds in 10 years in Latvia [15]).

After the statistical data was structured and analyzed, authors concentrated on the detailed study of the construction industry of Latvia, trying to determine the main challenges it faces. For that purpose, the authors analysed construction enterprises for the period from 2014 to 2017 (including) and interviewed industry professionals and academic experts to evaluate the employee turnover rate (Tables 4 and 5). 
Table 4. The data of the companies whose representatives were interviewed.

\begin{tabular}{cccc}
\hline Entity's Scale & Turnover (2017) & Number of Employees & Countries of Presence \\
\hline large & 60 MEUR & 100 & 3 \\
\hline large & 65 MEUR & 390 & 3 \\
\hline large & 92 MEUR & 950 & 6 \\
\hline medium & 12 MEUR & 240 & 1 \\
\hline medium & 17 MEUR & 200 & 4 \\
\hline medium & 21 MEUR & 255 & 4 \\
\hline medium & 11 MEUR & 200 & 2 \\
\hline small & 0.5 MEUR & 35 & 1 \\
\hline small & 3 MEUR & 50 & 1 \\
\hline
\end{tabular}

Table 5. Evaluation of the actual factors by industry and university representatives.

\begin{tabular}{cccc}
\hline $\begin{array}{c}\text { Factor/Factor's } \\
\text { Evaluation by }\end{array}$ & $\begin{array}{c}\text { Top Managers from } \\
\text { Industry }\end{array}$ & $\begin{array}{c}\text { Midlevel Managers } \\
\text { from Industry }\end{array}$ & $\begin{array}{c}\text { Professors from } \\
\text { University }\end{array}$ \\
\hline $\begin{array}{c}\text { Knowledge quality of } \\
\text { the new alumni }\end{array}$ & low & low & very good \\
\hline $\begin{array}{c}\text { Alumni's Specialization } \\
\text { Versus broad academic } \\
\text { knowledge }\end{array}$ & support specialization & support specialization & $\begin{array}{c}\text { support broad academic } \\
\text { knowledge }\end{array}$ \\
\hline $\begin{array}{c}\text { Cooperation with } \\
\text { universities/industry }\end{array}$ & $\begin{array}{c}\text { very low/almost does } \\
\text { not exist }\end{array}$ & $\begin{array}{c}\text { very low /almost does } \\
\text { not exist }\end{array}$ & normal \\
\hline $\begin{array}{c}\text { Understanding of the } \\
\text { reasons for the employee } \\
\text { leave }\end{array}$ & deep & deep & basic/ none \\
\hline $\begin{array}{c}\text { Understanding of the } \\
\text { main problems of the } \\
\text { industry }\end{array}$ & deep & deep & basic \\
\hline $\begin{array}{c}\text { Readiness to cooperate } \\
\text { with }\end{array}$ & midlevel & midlevel & midlevel \\
universities/industry & & & \\
\hline
\end{tabular}

The results showed that the most unstable situation appeared to be with the blue collars who are mainly motivated by wages. On the other hand, licensed professionals with higher education maintain a more loyal attitude to the company that they work for. The study also showed other factors apart from salaries that keep the employees with higher education motivated. It is important to underline here that the study was focused on the period of the last few years; this means that the complicated and tough world crisis period of 2008-2010 was excluded. However, the crisis left a deep impact on the small emerging economy (of Latvia) when the volume of the whole construction sector dropped by almost $57 \%$, forcing the most capable and active professionals to look for new opportunities outside Latvia, exploring big markets of the UK, Scandinavia, Germany, Russia etc. (based on [16]).

There are 5223 active registered construction companies in Latvia (based on Construction sectors of Latvia development strategy 2017-2024 [17]). This figure has remained almost the same for the last three years, absorbing minor fluctuations that can be ignored. The total turnover of the construction industry remained the same in 2014 and 2015, standing at about EUR 1.75 billion, while it experienced a sharp decline of almost 19\% in 2016, reaching the pivot of a bit above EUR 1.4 billion. The first three quarters of 2017 summarised the overall construction product at few points below EUR 1.2 billion, indicating that 2017 will show a recovery and may get close to the results of 2016. 
There was a minor overall price increase of about $2 \%$ when comparing the data for 2014 and up to $10 \%$ in 2017. However, the growth of wages and salaries for the same period was more than $16 \%$. Keeping in mind that the construction industry is mainly based on long-term projects, the statistical data for the certain period actually reflect 6-12 month old real data. This peculiarity, in combination with the number of started projects and final distribution of EU funds within the economy, indicates the problem in labour force and its adequate costs. Another issue that has a direct impact on the construction costs in general and wages and salaries, in particular, is the shadow economy. Wages that are paid in cash are still a problem within the industry. Latvia introduced a lot of resources in fighting this situation. As a positive result of the effort, the amount of wages and salaries paid officially increased. However, this has a serious impact on the employer's costs for the employee since Latvia has a high tax burden of about $78 \%$ above the net remuneration that the employee receives.

Based on the aforementioned factors, the authors conclude that social aspects (especially the educational level of human resources and the way of management) have an important impact on the development of construction companies. Thus, social innovation should be incorporated and taken into account forming further development strategy for the construction industry in the emerging small economies. The authors support the concept of deeper involvement of the construction companies in the social innovation processes, as presented in the Matrix of businesses with the social mission on the immature state of the key market [18], that in its turn should improve both the quality and productivity of the human potential within the industry.

According to the industry's data and expert opinions, there was a high staff turnover ratio, especially for the blue-collar employees who are mainly motivated by the size of their salaries. The flow of engineers or other employees with a higher education was not that high. It is also based on different reasons, not only salary, when a decision is made to stay in the company or change jobs. Based on the received data, the authors decided to concentrate on motivational factors affecting engineers in order to develop a cooperation model between the academic world and the industry that should provide additional incentives and improve the situation with human resources in a small emerging economy.

\subsubsection{Legislation Framework Analysis}

The strategy for the development within the construction sphere in Latvia for the years 2017-2024 emphasises that in the nearest 10 years, the engineering technical knowledge of the industry shall integrate with new competencies: ICT technologies, smart production, energy saving, building of passive houses. Therefore, educational institutions shall improve basic and new technology programmes along with introducing new social and digital competencies. An enhanced interest in the construction sphere shall be promoted among potential students and future professionals. New architects and construction engineers shall see the industry as constantly developing and, at the same time, a safe and motivating environment. It is very important for the industry to attract the most talented youth in the future, therefore the country shall establish a scientific educational centre in order to create primary interest, where children would learn interesting facts about the industry and production of construction materials, the history of the construction industry in Latvia in an entertaining manner and obtain primary construction skills.

The objective of the European Commission is to promote a favourable framework to boost competitiveness and support sustainable growth in the sector. The strategic objectives of the Latvian construction sector support the goals of the European Union's construction sector 2020, which are emphasised in the context of this research as follows: to improve the human capital database in the construction sector; to improve resource efficiency; to promote the competitiveness of EU construction companies globally.

Thus, the authors decided to investigate what is the most effective model for long-term cooperation between an academic state school and the private construction sector. According to 
expert opinions and the results of the survey conducted by the authors, the cooperation should solve the following tasks:

(a) support and develop the industry;

(b) attract more prospective students to the technical universities;

(c) involve students in real and ongoing projects from the very beginning of their studies;

(d) assist students in choosing a professional field that fits both their interests and abilities;

(e) improve communication and increase the involvement of the academics in strategic and operational challenges of the industry;

(f) increase the competitiveness of the particular industry and the state;

(g) attract more investments into both scientific researches and the construction sector.

\subsubsection{Key Literature Studies on Future Competencies for Construction Industry Employees}

Employees create a benefit for the enterprise and its profit; otherwise, the result of their activity causes losses. As Hill and Jones [19] declare, "Effective use of the human resources is essential for the competitiveness of the enterprise". Caputo and Pizzi [20] found that the number of employees is one of the main factors that affects a company's performance. Effective management of human capital is an integral part of the enterprise management, allowing goals to be achieved.

T. Schultz in 1979 and G. Becker in 1992 were awarded the Nobel Prize in Economics for the elaboration of the human capital theory. According to the conclusions of G. Becker, human capital analysis can help in explaining various regularities in the labour market and in the national economy as a whole. The term "human capital" is used in the context of investments, with contribution to employee growth, development and activity promotion since the return on investments manifests itself in the results of the enterprise activity—by educating individuals on their skills and knowledge, this increases the productiveness of its economic activity [21].

The ecosystem of an enterprise has been analysed since the early 21st century, and Isenberg [1] is considered as one of the founders of the idea of enterprise ecosystems who back in 2011 in his article "How to Start an Entrepreneurial Revolution", emphasised the essential meaning of the entrepreneurial environment (ecosystem) in the development of the enterprises, putting a special accent on the meaning of the financial and human resources (From reports and presentations on c [22]).

In the late 20th and early 21st century, the cooperation of academic organisations and the industry resulted in a different viewpoint, taking into account the global tendencies and most actual initiatives of the European Union, which characterise the future development of Europe and where academic organisations have an essential role in its implementation, hence the activity of academic organisations transformations [19]: the learning process and its implementation are constantly being improved, didactics of universities and colleges being changed and the role of collaboration between academic organisations and the industry becomes even more important.

Universities of the third generation are being established where cooperation with the industry becomes a third pillar along with the classical ones—studies and scientific activity [23].

According to Lee [24], the experiment of university-industry collaboration has been under way for nearly 20 years and it is appropriate to examine its history relative to actual benefits and draw inferences about the future of their collaboration. The initial wave of policy research in this area has produced a reasonably good understanding of what structural adjustments are needed when universities and the industry collaborate, and what institutional self-interest, together with cultural bias and prejudices, they must overcome if collaboration is to become a successful enterprise [25].

Lee [24] has made a table that summarizes the underlying motivations of university faculty and firms when collaborating on research and development projects. The table (Table 6) shows the motivation reasons which are listed in hierarchical order, from the most important to the least important. For faculty members, the most important reasons, the top four on the list, in collaborating with the industry are reasons of academic basic research. This must be reassuring to the academic 
community. Fortunately, too, the least important reason to these faculty members is entrepreneurial opportunity. When competing against the need for research support, pedagogical functions and outreach obligation also take a back seat [24].

Table 6. Hierarchy of the underlying motivations of university faculty and firms manifested in research collaboration.

\begin{tabular}{llll}
\hline Ranking & What Firms Seek from Academics & Ranking & What Academics Seek from Firms \\
\hline 1 & Research on product development & 1 & $\begin{array}{l}\text { Secure funds for graduate assistants and } \\
\text { lab equipment }\end{array}$ \\
\hline 2 & $\begin{array}{l}\text { Conduct 'blue sky' research in search } \\
\text { of new technology }\end{array}$ & 2 & Gain insight into one's own research \\
\hline 3 & Solve technical problems & 3 & Field-test application of one's own theory \\
\hline 4 & Design prototypes & 4 & Supplement funds of one's own research \\
\hline 5 & Provide seminars and workshops & 5 & Assist university's outreach mission \\
\hline 6 & Conduct fundamental research & 6 & Create student jobs and internships \\
\hline 7 & Support universities & 7 & Gain knowledge useful for teaching \\
\hline 8 & Develop software & 8 & Look for business opportunity \\
\hline
\end{tabular}

\subsection{Analysis of University-Industry Cooperation Models}

Following the expected research results and academic findings such as JinHyo Joseph Yun [26], DongKyu Won and Kyungbae Park who developed a conceptual model that allows him to forecast the dynamic effects of open innovation using a model-based analysis approach [26], the authors suggest their own developed model of cooperation between the private construction sector and the academic institutions in the small emerging economies.

According to Grant and Baden-Fuller [27], large companies have pulled back their corporate borders through outsourcing and divestment of "non-core" activities and have increasingly cooperated with other companies in order to engage in activities and access resources outside their own boundaries.

Many scientists (e.g., Maietta 2015 [28]) have examined another aspect of the activities that companies do not care about by themselves only-collaboration with universities. According to scientists' research (Cohen et al., 2002 [29], Mansfield, 1995 [30], Rosenberg and Nelson, 1994 [31]), university-industry collaborations in science and technology-based industrial sectors has long been recognized as an important source of economic growth [29].

Firms with strong scientific research focus may depend less on university collaborations for scientific novelty because these firms typically engage internal scientists: (1) to develop the basic scientific knowledge and know-how that may overlap with university research, and (2) to act as boundary spanners who can draw on scientific resources and expertise from the broader scientific community. On the contrary, firms with a strong technological recombination focus enjoy greater benefits from university collaborations because the experimental problem solving approach that is emphasized in technological recombination facilitates the process of translating scientific discoveries into technological innovations [32].

The authors offer the promotion of cooperation between the academic organisation and the industry which is aimed at national economy development, certain national economy (production areas) development or renewal and knowledge transfer and build-up (development of intellectual capital), thus forming a University-Industry cooperation model.

This creates a mutual profit because of the industry's access to talented and qualified labour force; on the other hand, it is impossible for the academic organisation to conduct research projects without partners from the industry-both the industry and the university possess understanding about the need for a dual education programme.

Cooperation models, cooperation promotion and motivation events are examined (awareness of the good practice of Latvia and other countries, data summary and theoretical grounding) along 
with the experience of foreign countries in the field of forming cooperation models between academic organisations and the industry in the context of the ecosystem of innovations.

A variety of cooperation models was analysed within the research: Carnegie Mellon University experienced U.S. construction engineers' work with colleagues in Israel, Brazil and Turkey, Strabag has several different cooperation programs, Vinci Construction signed a memorandum of understanding with the University of Malay, HOCHTIEF is one of the founding members of ENCORD (European Network of Construction Companies for Research and Development), etc. After analysing the university-industry cooperation models, the authors concluded that most of them are conducted by the companies with a turnover several times exceeding the budget of Latvia or another similar economy. This can be explained by the knowledge that the mentioned economies possess under globalization that is supported by multinational corporations [4]. However, the models that are used by global corporations acting in large scale economies should be reviewed and adjusted for the small markets.

The following questions were discussed in the current research:

$>$ What is the right cooperation model for a small emerging economy that faces various challenges and develops in an unstable environment?

$>$ What are the risks to eliminate and what are the strengths to leverage?

\subsection{Labour Force Competencies for the Construction Sphere and Market Analysis and New Multi-Competence Development Necessity}

The authors analyse necessary labour force competencies for the construction sphere and market and assess the necessity of a new multi-competence development, which is important for entrepreneurship development.

Regarding education in Latvia, the theoretical base is adequately well developed in various professions, yet new specialists often lack practical knowledge and skills right after graduation.

Qualified human resources are the milestone of development, promoting persistence and competitiveness for both construction entrepreneurs and construction sphere development as a whole. The goal here is to have highly qualified specialists in every construction profession, from drivers, architects and construction engineers to construction workers. A qualified worker in the industrial meaning is a highly-motivated person who is willing to belong to the construction industry, possessing good theoretical base matching world development tendencies and the ability to use theory in practice and recognising his/her professional liability. At the moment, there are about 70,000 employees in the construction sphere, of which 8500 certified construction specialists are listed in the Register of Construction Specialists (highly-qualified specialists and drivers). Construction and production of construction materials are the labour force consuming spheres where demand for qualified specialists in the competing market environment will increase (based on [5]).

During January-May 2018, the authors conducted 17 interviews. Among the interviewed persons, there were 12 top managers from private construction companies and five representatives of the academic staff from the Faculty of Civil Engineering of Riga Technical University. The following main ideas were discussed during the interviews:

(1) There is a difference between the perception of academics and industry representatives as to the professional competence and knowledge quality level of the newly graduated students. The top managers from private companies consider it as not sufficient, while Riga Technical university professors evaluate it as good when the best students are equal or even surpass alumni from West European universities;

(2) The University thinks that a broad general basis allows students to be better prepared, while the industry wants them to be particularly provided with extensive knowledge in the profession that they choose; 
(3) The cooperation between universities and the industry is more exceptional rather than routine. There are no special programs or other platforms where both parties can cooperate;

(4) On the academic side, there is a shallow understanding of reasons why employees leave their companies. According to the industry, the main reasons are: inadequate remuneration, lack of growth, intensive load, lack of professional challenges, availability of jobs abroad;

(5) There is a lack of professional personnel in the construction sector;

(6) The industry suffers from both low productivity and poor efficiency;

(7) Companies are interested in cooperation with universities to develop and attract young professionals;

(8) The University should have more financial freedom and should attract more private customers so that it can raise the quality of students' knowledge instead of chasing the quantity;

(9) The university believes that students should obtain broad range education, the scientific and professional basics and the ability to adapt. The post graduates should develop necessary skills by themselves while working. Whereas, the private sector representatives want the students to be prepared for work in real conditions having necessary (specific) knowledge for the profession that they choose.

The statistic survey among construction companies was conducted based on the interviews and 411 respondents confirmed the issues that were raised and discussed in the interviews.

The survey results outlined the following major factors affecting the motivation and engagement of the white-collar employees:

(1) The most important motivators for the construction sector are financial remuneration, social package and professional challenges and growth;

(2) $94.5 \%$ of the respondents agreed that newly post-graduated engineers are not able to work independently for the first five years;

(3) The level of the educational and professional readiness of students is not sufficient;

(4) There is a huge lack of professionals in all fields. The open EU labour market incites the workforce's outflow to the developed and big economies;

(5) The leading opinion of the sector is that the existing bureaucracy in the field hinders rather than assists;

(6) $71 \%$ of the engineers agree to share their knowledge and cooperate with the university;

(7) The productivity of the blue collars is affected by the professional skills of the foreman

(8) $61 \%$ consider that the received salary corresponds with his/her knowledge and performed work.

The interviewed employees with longer experience in the workplace and a more responsible position pointed out that their professional skills and competencies were not properly used at work (Figure 2); when evaluating their willingness to interact and asking whether those individuals would be willing to share their knowledge with the university to share their practical knowledge with students studying construction, the conclusion was (Figure 3) that the interviewed professionals would like to do it (in the graphs, the concentration of dots indicates consent, and the greater the acceptance is, the closer the curves come to each other, as well as the put together parameters: positions and work experience in the industry/workplace).

The third diagram (Figure 4) shows that senior executives, regardless of their experience in the company or industry, in $61 \%$ of their responses indicate that their colleagues were not able to work independently after graduation; in $56 \%$ of cases, the respondents agreed that their colleagues could work independently after at least 10 years of experience. This opinion of industry respondents also justifies the opinion of the educational institution officials who pointed out that it is impossible for a higher educational institution to meet the industry's desire to have absolutely prepared graduates since at least 5-10 years of practical experience in the industry is necessary to work independently. 
Multiple Correspondence Analysis plot of q1, q2, q4 vs q9_3

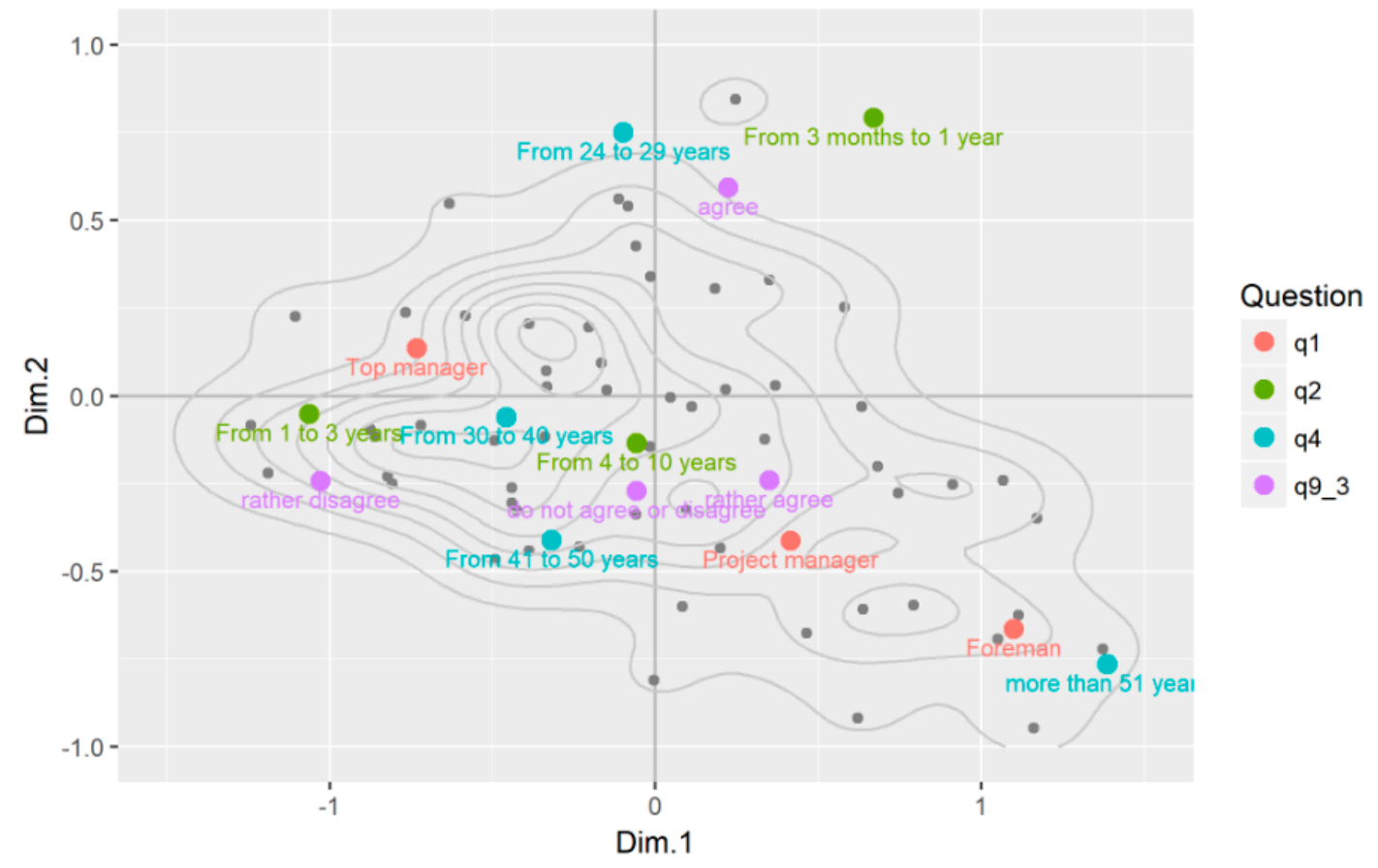

Figure 2. Answers to the question: I have skills and abilities that are not used in my work.

Multiple Correspondence Analysis plot of q1, q3, q4 vs q19

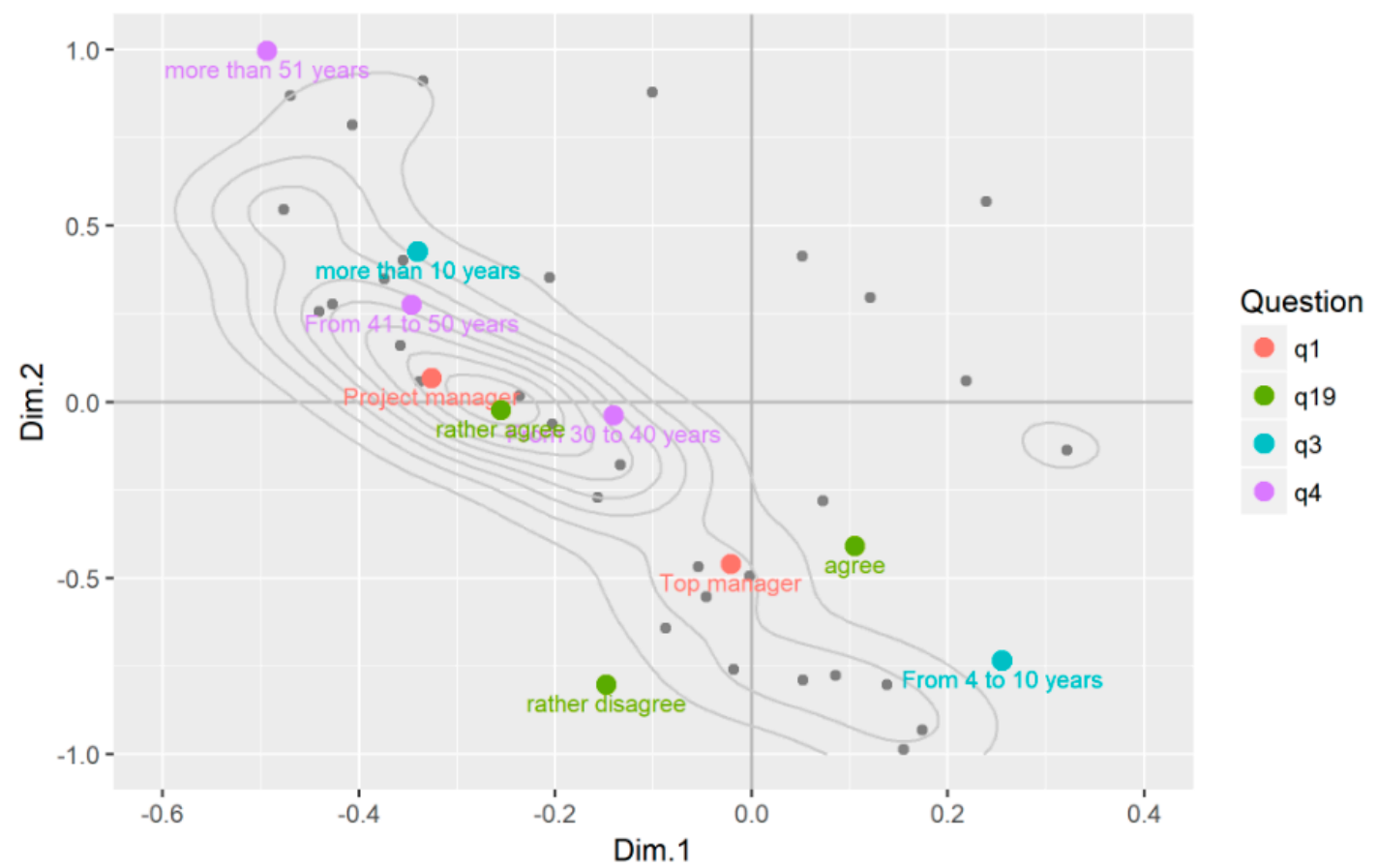

Figure 3. Answers to the question: I am willing to work with the university to teach. 


\section{Multiple Correspondence Analysis plot of q1, q2 vs q16_1}

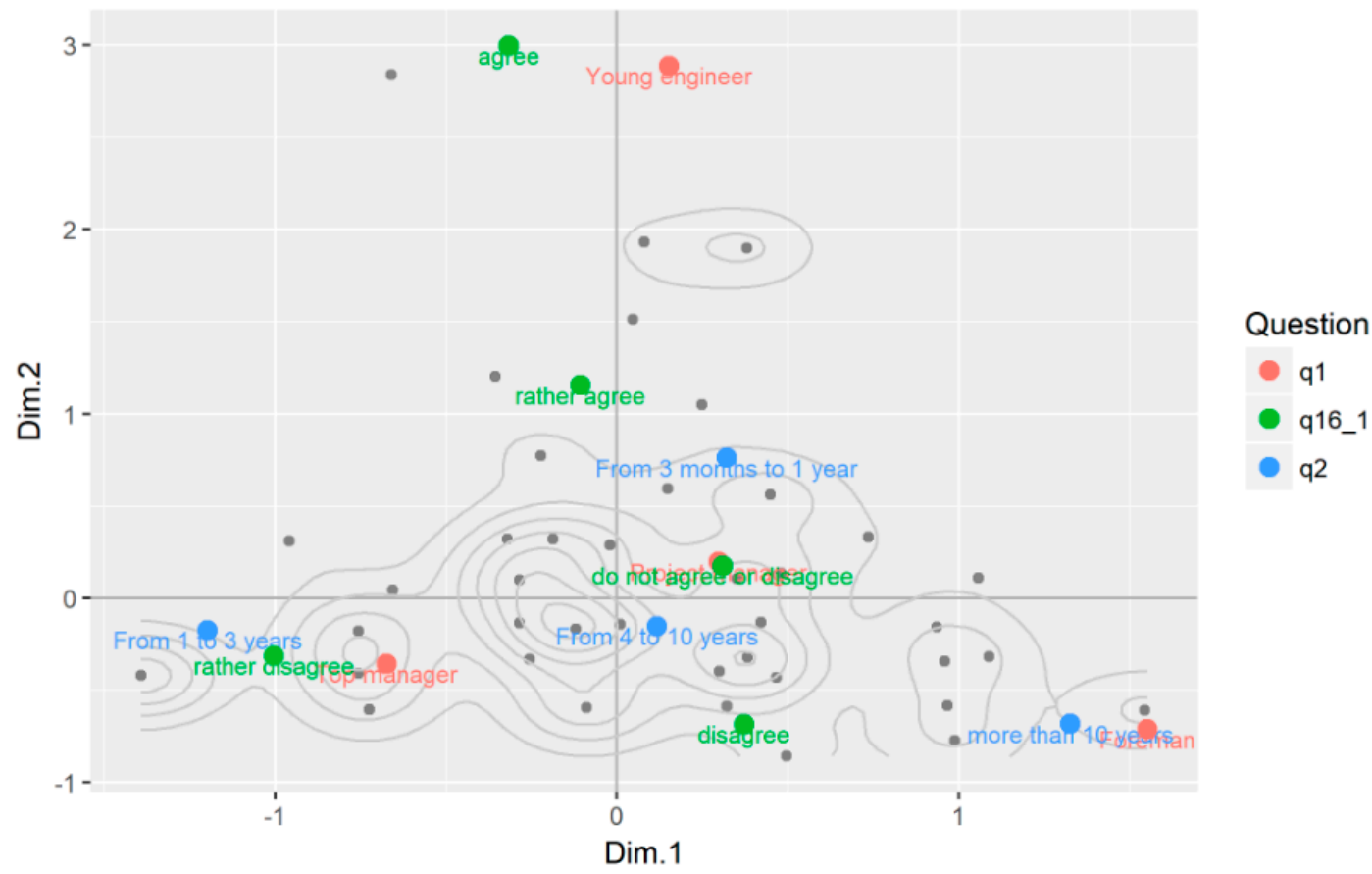

Figure 4. Answers to the question: My colleagues work independently after graduation.

The fourth diagram (Figure 5) supplements the previous one because $47 \%$ of the respondents admit that there is a shortage of skilled employees in the company; only the younger specialists evaluate the situation in a more positive way, while the specialists with long experience in the industry evaluate the lack of readiness of human resources to perform their duties.

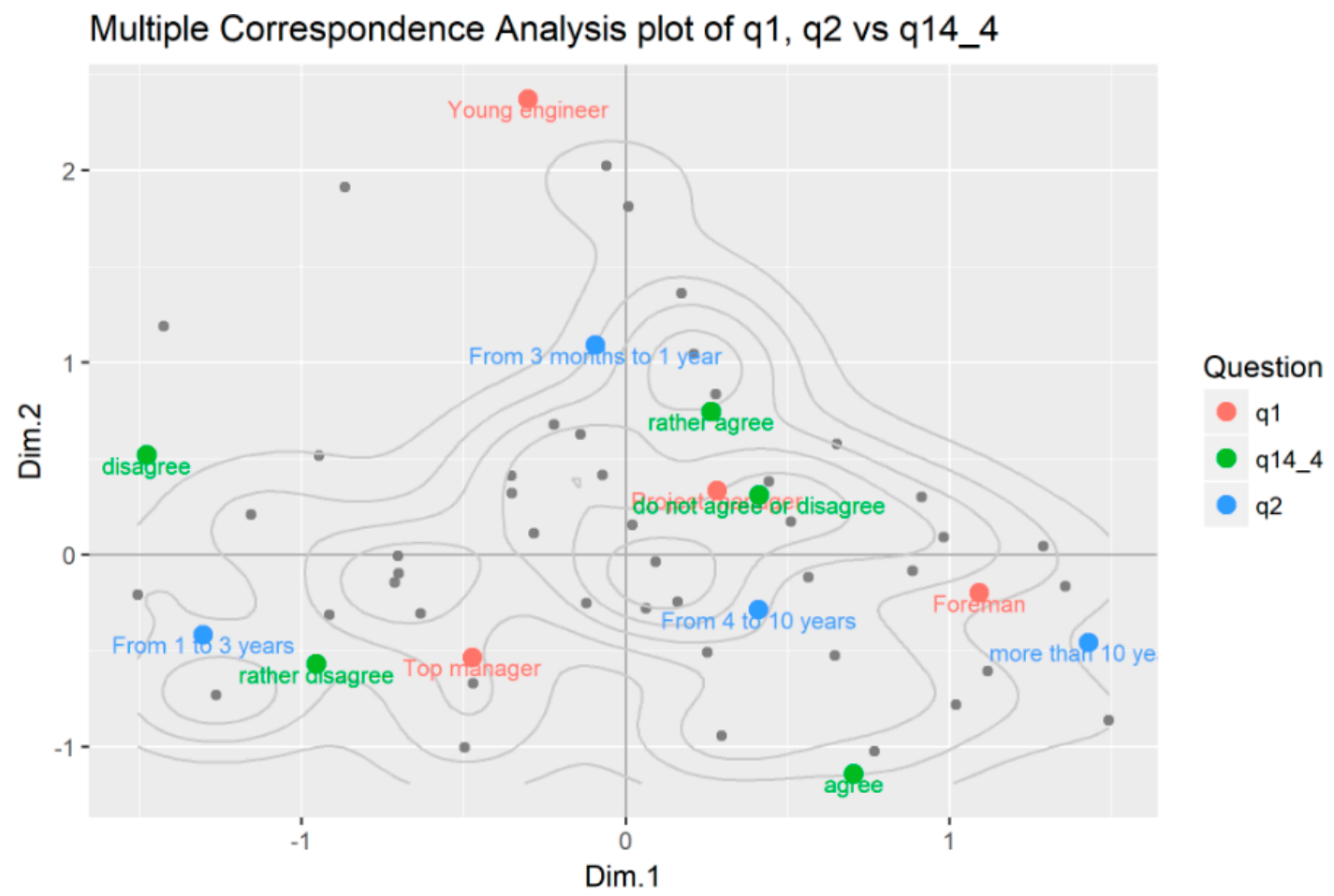

Figure 5. Answers to the question: there is a shortage of skilled employees in the company. 
To analyse the obtained data, the authors use multiple correspondence analysis (MCA). This is a data analysis technique for nominal categorical data that is used to detect and represent underlying structures in a data set. Analysing the indicator matrix allows the direct representation of individuals as points in geometric space. Analysing the Burt Table is a more natural generalization of simple correspondence analysis, and individuals or the means of groups of individuals can be added as supplementary points to the graphical display.

In the indicator matrix approach, associations between variables are uncovered by calculating the chi-square distance between different categories of the variables and between the individuals (or respondents). These associations are then represented graphically as "maps", which eases the interpretation of the structures in the data. Oppositions between rows and columns are then maximized in order to uncover the underlying dimensions that are best able to describe the central oppositions in the data. As in factor analysis or principal component analysis, the first axis is the most important dimension, the second axis is the second most important, and so on, in terms of the amount of variance accounted for. The number of axes to be retained for analysis is determined by calculating modified eigenvalues [33].

The authors defined some reasons why the industry should cooperate with the universities which are: to solve specific technical or design problems, to make measurements, in some cases to get new ideas for developing new products; to improve product quality, to have access to new research, to organize problem solving workshops, to maintain relationships and network with the university, to recruit university graduates.

\section{Conclusions, Results and Discussion}

The lack of a clear state policy and, more importantly, the lack of political will in implementing even what is already prepared is one of the main problems. The challenges and deficiencies determined in this article may serve as a basis for further research.

The authors used the triangulation method to analyse the construction industry, legislation framework and literature studies. The results were validated during the interviews and the survey. The illustrative figures (Figures 2-5) show the most explicit samples of the performed survey. The authors proved that both the construction industry and the universities are very state regulated. Therefore, the Triple Helix model appeared to be the most suitable to describe the mutual interaction.

The elaborated model of cooperation between the state, society, universities and industry is based on the interviews with construction sector professionals, experts and academics that provided their views on the current situation. Another input via a survey was received from more than 400 employees with college and higher education who work in the construction sphere. The model allows either solving or minimizing the main problems that both the construction sector and the academics are facing.

Each small economy should set national priorities and have a willingness to stick to the chosen path. Estonia is a great example of the state that persistently invests and develops the fields that it has chosen as strategic ones.

The challenges and deficiencies determined in this article may serve as a basis for further research.

\section{Research Results}

The aim of this research is to suggest the most effective model for long-term cooperation between an academic university and the private construction sector of the emerging small economy through the comprehensive study of the existing ways of collaboration between universities and the construction industry.

Conclusions are supported by both findings of other scientists, such as Tsuori M., and results of the current research [34]. The model, designed by the authors, suggests a way of how to cooperate with a mutual benefit when both private companies and universities help each other to improve the situation. 
The first macro level problem that affects only universities is their system of financing. There are several models and different goals set by the EU, UN, national development programs, etc. that are expected to be fulfilled. We will not get involved in a discussion whether there is a real need for $30 \% / 40 \% / 50 \%$ of the EU population to have higher education or not. We will leave this for other researchers, however such a quantitative requirement obliges the particular state to follow this pan-European plan. As a result, many countries provide the policy "Money follows the student", believing that this increases the number of students, however it does not allow one to raise the quality of their education. This happens due to the limited academic human resources and due to the quality of the students themselves who are admitted for studies with very low or non-existent criteria. To promote the quality of education, the universities together with the ministries of finance and education should develop a new or adopt the existing financing model that would ensure a certain fixed budget that does not depend on the number of students. This financial approach should also include some variables of additional incentives (the university improved its ranking, made a breakthrough in a scientific field, students were examined by an independent body or another university and results were higher than a certain level, the university attracted a significant private customer and it can keep this fee for internal development, etc.) that are needed to push universities to develop themselves.

Assuming that the aforementioned problem is solved, there are a few issues for discussion at the University-Industry level.

(1) Involvement of the tutors in the real sector;

(2) Involvement of the real sector representatives in the educational process;

(3) Involvement of the international tutors;

(4) Involvement of the students in the real sector;

(5) Specialization of the students.

The first two issues could be solved by inviting working specialists to lecture. They most probably cannot lead the scientific work, however they may explain how the industry operates in real life, what the skills are and the knowledge that is needed for the particular specialty. The industry has to be involved in the program development as well. Tutors of all levels may have a certain practice period in the construction company, however the company should be compensated for the time and resources spent to train the academics. A similar project was initiated in Latvia, however it has not been launched yet.

International input is essential. Small countries should get as much as possible from outside in order to not stay behind. Thus, exchange programs, guest lecturers from abroad and permanent staff from different countries will improve both the level of knowledge and the perception of the university in the world.

Specialization of the students is also essential. Minimum time should be spent by the company to train the newly graduated engineers. There is no need for the foreman to know the same things that the structural designer knows, and vice versa. This does not mean that each of them shall be limited by his/her narrow field only, knowing nothing about other spheres. The fundamental basics shall be the same, however students shall have deep expertise in the field that they are interested in and shall gain general information to complement their specialization.

The last but not least question is about students' involvement in the industry. Here come the financial options in possession of each particular university. If the number of students is not big, they may get better support from the university, allowing them to concentrate on studies only. During the first years when the fundamental theoretical subjects are taught, students should study at the university, however after three years, they should choose the specialization that they want and get a job in that field. The time before the student gets the diploma may be extended up to 5-6 years. This way, it will provide an opportunity to have time for normal practice and work.

After the first three years, students may switch to the evening study hours while working in the morning. Students may be issued special scholarships compensated in part or in full by the company. 
This scholarship issued by the private company is beneficial since almost no taxes are to be paid; sometimes even tax is deductible as any payment to the university. The university can also benefit from the arrangement, reducing its expenses on each particular student. If a student does not study properly, he/she does not receive a scholarship. Part of the scholarship may be paid after receiving the diploma so that students are motivated to continue their studies. This model allows companies to receive employees with theoretical background and proceed with proper training to the benefit of both parties.

If all five points are implemented, a significant improvement is expected within a relatively short time period. The synergy and symbiosis of the educational process and the industry will develop in a short time. The limited number of places in the universities shall ensure that only those who are really keen to work in construction and are motivated to become well-trained professionals are accepted. The involvement of the representatives from the construction sector will provide them with an opportunity to communicate with the students and invite the most willing ones to undergo practical studies. The students will better understand the real-world issues and will make better thought-out choices of their future profession.

The scholarship program shall push students to work and study hard to receive more money. The construction companies shall have an option to train students with minimum costs, providing them with an option to stay in the company and, what is much more important, most of these young engineers will know what they want to do after graduation and will be able to fulfil their duties with minimal training from the employer's side.

The suggested cooperation model may provide a general guideline for further detailed researches and its implementation may help similar-sized economies to make national adjustments. The implementation of this model in bigger and/or developed economies should be justified by separate additional research.

These findings provide a broad field for further studies and researches which may focus either on the construction industry only or expand to other industries with similar operational models.

Changes are necessary for the construction sphere of Latvia, raising its productiveness, innovations, exportability, as well as highlighting achievements in the construction area. Tendencies of the industry development demand professional qualified specialists with the necessary education: architects, construction engineers, etc., whereas the authors offer to make a uniform database in order to attract and select performers of physical work.

Author Contributions: Conceptualization, E.G.-S.; methodology, E.G.-S.; validation, J.L. and Z.R.; formal analysis, Z.R.; writing—original draft preparation, Z.R. and J.L.; writing—review and editing, Z.R. and J.L.

Funding: This research received no external funding.

Conflicts of Interest: The authors declare no conflict of interest.

\section{References}

1. Isenberg, D. Introducing the Entrepreneurship Ecosystem: Four Defining Characteristics. Forbes. 2011. Available online: http://www.forbes.com/sites/danisenberg/2011/05/25/introducing-theentrepreneurship-ecosystem-four-defining-characteristics/\#7505355e38c4 (accessed on 20 December 2018).

2. Etzkowitz, H.; Leydesdorff, L. The Triple Helix Concept. Available online: http:/ / triplehelix.stanford.edu/ 3helix_concept (accessed on 20 December 2018).

3. Mangialardo, A.; Micelli, E. Rethinking the Construction Industry under the Circular Economy: Principles and Case Studies, Smart and Sustainable Planning for Cities and Regions 2017; Springer: Berlin, Germany, 2017.

4. Cooke, P. The virtues of variety in regional innovation systems and entrepreneurial ecosystems. J. Open Innov. Technol. Mark. Complex. 2016, 2, 13. [CrossRef]

5. Active Registered Construction Companies. Construction Information System. Available online: https:/ / bis.gov.lv/bisp/statistika/buvkomersantu-registrs/buvkomersantu-registra-statistika-par2017-2018-gadiem (accessed on 19 December 2018). 
6. Bosma, N.; Amorós, J.E. Global Entrepreneurship Monitor (GEM) Executive Report. Available online: https:/ / www.researchgate.net/publication/241885424 (accessed on 20 December 2018).

7. Erkut, B. Structural similarities of economies for innovation and competitiveness-a decision tree based approach. Studia Oeconomica Posnaniensia 2016, 4, 85-104. [CrossRef]

8. Worldbank. Population Density (People per sq. km of Land Area). Available online: http://data.worldbank. org/indicator/EN.POP.DNST (accessed on 20 December 2018).

9. Eurostat. Population Change-Demographic Balance and Crude Rates at National Level. Available online: http:/ / appsso.eurostat.ec.europa.eu/nui/show.do?dataset=demo_gind\&lang=ne/ / (accessed on 7 April 2017).

10. Eurostat. Labour Cost Levels by NACE Rev.2 Activity. Available online: http:/ / ec.europa.eu/eurostat/tgm/ table.do?tab=table\&init=1\&language=en\&pcode=tps00173\&plugin=1 (accessed on 11 April 2017).

11. Deloitte. European Salary Survey 2015. General Decrease in Costs and Housing in Europe; Deloitte: London, UK, 2015; pp. 32-34.

12. Central Statistical Bureau of Latvia. Labour Cost Index. Available online: http://www.csb.gov.lv/en/ statistikas-temas/metodologija/labour-cost-index-36980.html (accessed on 20 December 2018).

13. Adamovic, M. Europe: Cost of Living Index by Country. Available online: https:/ / www.numbeo.com/ costofliving/rankings_by_country.jsp?title=2016\&region=150 (accessed on 20 December 2018).

14. World University Rankings (2016-2017). Available online: https://www.timeshighereducation.com/worlduniversity-rankings/2017/worldranking\#!/page/0/length/25/sort_by/rank/sort_order/asc/cols/stats (accessed on 20 December 2018).

15. EU Funds. Done in 10 Years? Infographics about EU Funds in 10 Years in Latvia. Available online: http:/ / esfondi.lv/upload/infografikas/infografika_ek.jpg (accessed on 20 December 2018).

16. Informative Report on Medium and Long-Term Labor Market Forecasts in Latvia. 2016. Available online: https://www.em.gov.lv/files/tautsaimniecibas_attistiba/dsp/EMZino_06_160616.pdf (accessed on 20 December 2018).

17. Construction Sectors of Latvia Development Strategy 2017-2024. Available online: https://www.em.gov.lv / files/buvnieciba/BS_17.05.2017.pdf (accessed on 20 December 2018).

18. Svirina, A.; Zabbarova, A.; Oganisjana, K. Implementing open innovation concept in social business. J. Open Innov. Technol. Mark. Complex. 2016, 2, 20. [CrossRef]

19. Hill, C.W.L.; Jones, G.R. Strategic Management Theory, 9th ed.; Houghton Mifflin Company: Boston, MA, USA, 2009.

20. Caputo, F.; Pizzi, S. Ethical firms and web reporting: Empirical evidence about the voluntary adoption of the Italian "legality rating". Int. J. Manag. 2019, 14, 36-45. [CrossRef]

21. Armstrong, M. A Handbook of Human Resource Management Practice: 10th Edition; Kogan Page: London, UK; Philadelphia, PA, USA, 2006.

22. Fourteen Country-Level Reports and Presentations on University-Business Cooperation. 2010/2011. Available online: https: / www.ub-cooperation.eu/index/presentations (accessed on 20 December 2018).

23. Wissema, J.G. Towards the Third Generation University: Managing the University in Transition; Edward Elgar Publishing: Cheltenham, UK, 2009.

24. Lee, Y.S. The sustainability of university-industry research collaboration: An empirical assessment. J. Technol. Transf. 2000, 25, 111-133. [CrossRef]

25. Blumenthal, D.; Cluck, M.; Louis, K.S.; Soto, M.A.; Wishe, D. University-industry research relationships in biotechnology: Implications for the university. Science 1986, 232, 1361-1366. [CrossRef] [PubMed]

26. Yun, J.J.; Won, D.; Park, K. Dynamics from open innovation to evolutionary change. J. Open Innov. Technol. Mark. Complex. 2016, 2, 7. [CrossRef]

27. Grant, R.M.; Baden-Fuller, C. A knowledge-based theory of inter-firm collaboration. In Proceedings of the Academy of Management Annual Meeting; Academy of Management: Briarcliff Manor, NY, USA, 1995.

28. Maietta, O.W. Determinants of university-firm R\&D collaboration and its impact on innovation: A perspective from a low-tech industry. Res. Policy 2015, 44, 1341-1359.

29. Cohen, L.; Manion, L.; Morrison, K. Research Methods in Education, 6th ed.; Routledge Publishers (part of the Taylor \& Francis group): Oxford, UK, 2007. Available online: https:/ /www.researchgate.net/publication/ 44824604_Research_Methods_in_Education (accessed on 20 December 2018). 
30. Mansfield, E. Academic Research Underlying Industrial Innovations. Rev. Econ. Stat. 1995, 77, 55-65. [CrossRef]

31. Rosenberg, N.; Nelson, R. American universities and technical advance in industry. Res. Policy 1994, 23, 323-348. [CrossRef]

32. Soh, P.H.; Subramanian, A.M. When do firms benefit from university-industry R\&D collaborations? The implications of firm R\&D focus on scientific research and technological recombination. J. Bus. Ventur. 2014, 29, 807-821.

33. Greenacre, M. Correspondence Analysis in Practice, 2nd ed.; Chapman \& Hall/CRC: London, UK, 2007.

34. Tsouri, M. Knowledge Networks in Emerging ICT Regional Innovation Systems: An Explorative Study of the Knowledge Network of Trentino ICT Innovation System. Ph.D. Thesis, University of Trento, Trento, Italy, 2017.

(c) 2019 by the authors. Licensee MDPI, Basel, Switzerland. This article is an open access article distributed under the terms and conditions of the Creative Commons Attribution (CC BY) license (http://creativecommons.org/licenses/by/4.0/). 